\title{
Fully Recovered Pediatric Traumatic Brain Injury Followed In Palliative Care Unit
}

\section{Palyatif Bakım Servisinde Takip Edilen Tam Iyileşme Gösteren Pediatrik Travmatik Beyin Hasarı}

\author{
Abdullah Kahraman \\ Department of Anesthesiology, Van State Education and Research Hospital, Health Science University, Ministry of \\ Health, Van, Turkey
}

\begin{abstract}
17-year-old generalized epileptic male patient with moderate mental retardation who has $94 \%$ disability report was discharged from our clinic having fully recovered from previous condition after 45 days of intensive care unit and 75 days palliative care unit monitorization due to fall from height.

Key Words: Brain injury, palliative care, paediatric patient
\end{abstract}

\section{Introduction}

Palliative care centres are getting widespread in our country and it is a multidisciplinary health project which provides rehabilitation opportunity after the acute intervention in these patient groups. In this research, we aimed to present a paediatric patient who was discharged from our clinic having fully recovered from previous after palliative care monitorization.

\section{Case Report}

17-year-old epileptic patient with moderate mental retardation was taken to intensive care unit from emergency service as intubated due to fall from height. The unconscious patient was intubated, Glasgow Coma Scale (GCS) 4, tension arterial $100 / 65 \mathrm{mmHg}$, hearth rate $105 \mathrm{bpm}$, peripheral oxygen saturation 100 , mechanically ventilated in SIMV mode with respiratory rate 14 , tidal volume $400 \mathrm{ml}$. In patient's CT and MRI, areas that comply with axonal injury were observed (Figure 1), steroid and mannitol for brain oedema treatment was applied. The patient was extubated on the $15^{\text {th }}$ day after his sufficient spontaneous ventilation. Percutaneous endoscopic gastrostomy (PEG) was applied due to lack of oral feeding ability. Because of extended pneumonia treatment

\section{ÖZET}

17 yaşında orta derece mental retarde, jenarilize epileptik ve \%94 özürlülük raporuna sahip erkek hasta yüksekten düşme nedeniyle 45 günlük yoğun bakım ünitesi ve 75 günlük palyatif bakım servisi takibi sonucunda tam olarak eski haline dönerek kliniğimizden taburcu edilmiştir.

Anahtar Kelimeler: Beyin hasarı, çocuk hasta, palyatif bakım

in intensive care unit, the patient was taken to palliative care unit on $45^{\text {th }}$ day of his hospitalization. The patient had tetraplegia, lung infection, and no ability to communicate. Medical treatment was planned. The patient's relatives were told to communicate with him, as if he would understand them. In 10 days, the patient started to make eye contact and recognize his doctor. Once the patient was observed to regain swallowing reflex, he was fed orally, on $50^{\text {th }}$ days of hospitalization PEG was removed. Increase in motor strength starting from lower extremity towards upper extremity was observed, muscle strengthening exercises were practiced by physical therapy program. The patient was discharged from palliative care on his $75^{\text {th }}$ day as he recovered and gained his physical and psychological condition before the event.

\section{Discussion}

Diffuse axonal injury (DAI), is the second most fatal traumatic clinical case after subdural hematoma. They make up 30\% of all fatal head trauma (1). Because of the fact that it can cause coma without traumatic mass effect, DAI is accepted as a "special" type of trauma (2). In its etiology, usually there are car and motorcycle

*Corresponding Author: Abdullah KAHRAMAN MD., Department of Anestesiology, Van State Education and Research Hospital, Health Science University, Ministry of Health, Van, Turkey, Phone: 0 (537) 72201 44, E-mail: abdullahhero100@gmail.com 


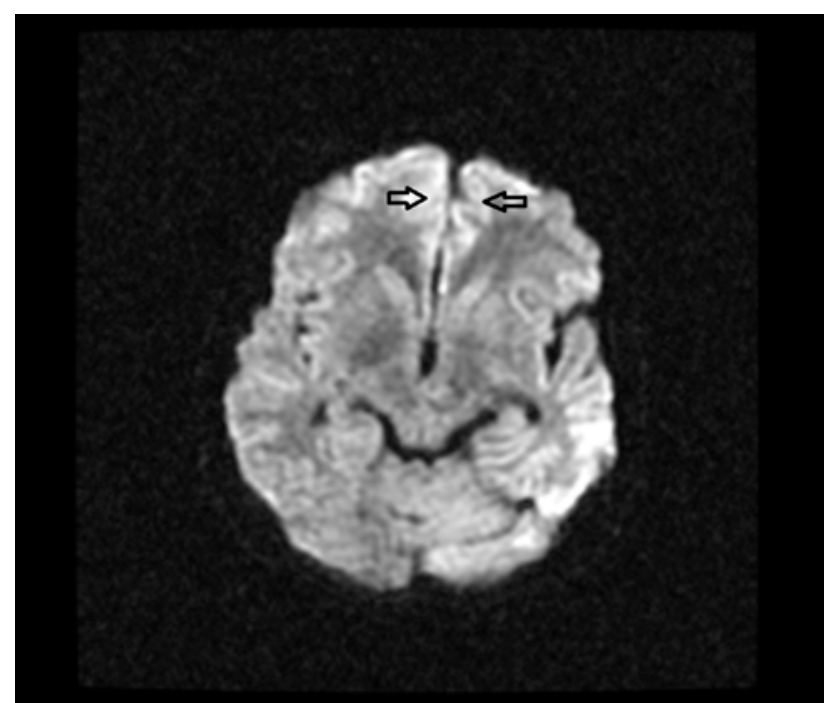

Fig. 1. Hyperintense foci of diffuse axonal injury are depicted

accidents. It has a prognosis scale from moderate coma that lasts 6 hours to an extended coma or serious neurological deficits (3).

DAI manifests itself with loss of consciousness at instant of trauma. Decrease of Glasgow coma scale in patients leads to midbrain or brain stem damage prediction rather than the cortex $(4,5)$. DAI is the most important cause of permanent vegetative disorder caused by traumatic brain damage. Cranial CT and MRI scanning after the injury are usually normal. Only in $10 \%$, hemorrhagic punctual lesions in corpus callosum and upper cerebral junction, grey or white essence in pontomesencephalic junction which are typical of DAI (6). In first two weeks of injury, ventricular dilatation, which is defined as hydrocephaly by mistake, occurs. In diagnosis of DAI, which is difficult to diagnose with traditional, conventional methods, the most important method is diffusion MRI. It can display proton ions movements within the traumatic area, within a couple of minutes of the trauma (7).

As a conclusion, palliative care centers are a multidisciplinary health care project that is increasingly prevalent in our country and provides rehabilitation after acute intervention to such patient groups.

\section{References}

1. Slazinski T, Johnson MC. Severe diffuse axonal iniuryin adults and children. J Neurosci Nurs 1994; 26(3): 151-154.

2. Imago $\mathrm{T}$, Kaze AM. Diffuse axonal iniury by simplefall. Am J Forensic Med Pathol 1992; 13(2): 169-172.

3. Hilton G. Diffuse axonal iniury. J Trauma Nurs 1995; 2(1): 7-12.

4. Consensus conference. Rehabilitation of persons with traumatic brain injury. NIH Consensus Development Panel on Rehabilitation of Persons With Traumatic Brain Injury. JAMA 1999; 282(10): 974-983.

5. Adams JH, Mitchell DE, Graham DI, Doyle D. Diffuse brain damage of immediate impact type: its relationship to "primarybrain-stem damage" in head injury. Brain 1977; 100(3): 489-502.

6. Thurman DJ, Alverson C, Kathleen AD, Guerrero J, Joseph E, Sniezek JE. Traumatic Brain Injury in the United States: A Public Health Perspective Journal of Head Trauma Rehabilitation 1999; 8(2): 11-18.

7. Meythaler JM, Peduzzi JD, Eleftheriou E, Novack TA. Current concepts: diffuse axonal injuryassociated traumatic brain injury. Arch Phys Med Rehabil 2001; 82(10): 1461-1471. 